\title{
BIOMARKERS IN COMMUNITY-ACQUIRED PNEUMONIA ASSESSMENT
}

\author{
Natalja Voskresenska ${ }^{1}$, Sergejs Babikovs ${ }^{1}$, Jūlija Voicehovskka ${ }^{1}$, Andrejs Šķesters ${ }^{2}$, \\ Alise Silova ${ }^{2}$, Vladimirs Voicehovskis ${ }^{1, \#}$, Renija Aleksejeva ${ }^{1}$, Aivars Lejnieks ${ }^{1}$, \\ and Jurijs Karpovs ${ }^{1}$ \\ ${ }^{1}$ Department of Internal Diseases, Riga Stradiṇš University, Dzirciema iela 16, Riga, LV-1007, LATVIA \\ ${ }^{2}$ Laboratory of Biochemistry, Riga Stradinš̌ University, Dzirciema iela 16, Riga, LV-1007, LATVIA \\ \# Corresponding author; vladimirs.voicehovskis@rsu.lv
}

Communicated by Aivars Lejnieks

\begin{abstract}
The paper presents information on pneumonia $(P)$ patients with features of oxidative stress (OS). Identifying features of OS in patients with $P$ is of interest not only for diagnosis, but also for monitoring of treatment efficiency. We recruited 73 patients with community-acquired $P(C A P)$, previously healthy adults, both males and females with mean age of $68.0 \pm 15.2$, hospitalised, and 61 healthy control patients matched for age. For quantitative evaluation of lipid peroxidation in CAP patients, the levels of aldehydic lipid peroxidation products like malondialdehyde (MDA) and 4hydroxynon-2-enal (HNE) were quantified. Furthermore, concentrations of reduced glutathione (GSH) and several antioxidant enzymes and selenium in plasma were determined. In CAP patients, decreased levels of GSH and plasma selenium were observed. Plasma levels of MDA, and HNE did significantly differ between patient and control groups. We also noted reduced activity of antioxidant enzymes, namely, glutation peroxidase and superoxide dismutase. Low antioxidant enzymes activity was associated with a more severe CAP pattern. Both GSH and antioxidant enzymes may serve as markers for inflammation-related OS in CAP patients, and measurement of these biomarkers may be a valid indentifier for its management.
\end{abstract}

Key words: pneumonia, oxidative stress, biomarkers, glutathione, antioxidant enzymes.

\section{INTRODUCTION}

Pneumonia $(\mathrm{P})$ is defined as an acute illness with cough and at least one of the following: new focal chest signs, fever for longer than four days or dyspnoea/tachypnoea, without other obvious cause, and radiographic evidence of lung shadowing that is likely to be new (File, 2003). The overall incidence of community-aquired $\mathrm{P}$ (CAP) in general practice in Europe is reported to range between 1.7 and 11.6 cases per 1000 people per year in adults. In the European Union (EU), about 3370000 cases are expected annually. Hospitalisation rates differ widely between European countries, ranging from $20-50 \%$, meaning that there are about 1 million hospital admissions for CAP per year in the EU (Welte et al., 2012). The 90-day mortality rate in the P patient population may reach 14\%; post-hospitalisation mortality is still considerably high within a year after discharge, in comparison to the general population and to patients hospitalised for other reasons (Wunderink and Waterer, 2014), However, mortality does not seem to be related to antibiotic resistance (Frei et al., 2010). CAP is associated with a significant increase in the risk of cardiovascular events and death from cardiac causes.
Rapid and precise diagnosis of CAP is still a relevant problem and there is no general accepted biomarker to confirm the diagnosis and to evaluate its severity to guide management. Inflammatory markers have different diagnostic cutoffs; their specificity and sensitivity remain insecure, and only a few of these have been validated for clinical use (Nickler et al., 2016). An ideal biomarker for CAP diagnosis should allow rapid diagnosis, have prognostic value and facilitate therapeutic decision making. We suggest that future clinical studies need to consider biomarkers of oxidative stress (OS), which are objectively measured and evaluated as indicators of normal biological processes, pathogenic processes and pharmacologic responses to therapeutic intervention.

Increased oxidative/nitrosative stress generally describes a condition in which cellular antioxidant (AO) defenses are inadequate to completely inactivate the reactive oxygen species (ROS) and reactive nitrogen species (RNS) generated, because of their excessive production, loss of AO defenses, or both. OS is now recognised to be a common mediator of many acute and chronic diseases and even of the normal aging process (Nathan and Cunningham-Bussel, 2013; Schaur 
et al., 2015;). A major consequence of OS is a variety of cellular responses through generation of secondary reactive species that eventually activate cell death by necrosis or apoptosis. Numerous studies support the idea that the OS pattern is disease-specific (Dalle-Donne et al., 2006; Watson, 2014; Ursini et al., 2016).

The airway epithelium is subject to oxidative damage from both exogenous oxidants (cigarette smoke, pollutants) and endogenous agents (phagocytes). It is accepted widely that airway infection promotes activation and recruitment of phagocytic cells in the lungs. OS as a component of pathogenesis is featured in several lung pathologies $-\mathrm{P}$, alveolitis, mucoviscidosis, chronic obstructive pulmonary disease, bronchial asthma, idiopathic pulmonary fibrosis, and acute respiratory distress syndrome (Barnes, 1990). Lung tissue contains large amounts of non-saturated fatty acids, which are a substrate for lipid peroxidation (LP). Oxidants that form during smoking act on the lungs directly. Previous study of AO dynamics showed that gamma-glutamylcysteine synthetase (gamma-GCS) mRNA is distorted in smoking patient airway epithelium cells (Taivans et al., 2001).

OS contributes significantly to inflammatory pathology of the lung and has important consequences in the pathogenesis of CAP, including oxidative inactivation of antiproteases and surfactants, mucus hypersecretion, membrane LP, alveolar epithelial injury, remodeling of extracellular matrix, and apoptosis. The distribution and effects of OS, as well as information regarding the nature of the ROS/RNS, may be gleaned from the analysis of discrete biomarkers of oxidative/nitrosative stress. LP generates plenty of relatively stable decomposition end products, mainly $\alpha, \beta$-unsaturated reactive aldehydes, such as malondialdehyde (MDA) and 4hydroxy-2-nonenal (HNE), which can then be measured in plasma and urine as an indirect index of OS. MDA is one of the most commonly reported biomarkers of LP in clinical studies. Nevertheless, the most relevant product of LP, when lipid hydroperoxides are decomposed, seems to be HNE. HNE may be viewed as a signal transducer of chronic conditions, and authors have recommended to study HNE in various processes (Poli et al., 2008, Ursini et al., 2016). Compared with free radicals (aldehydes), MDA/HNE is rather stable and exit from cells to several destinations. A negative association between HNE concentrations in pulmonary and airway epithelium was onserved in a study on neutrophils and lung function $\left(\mathrm{FEV}_{1}\right)$ in chronic obstructive pulmonary disease patients (Rahman et al., 2002).

The lung, like many other tissues, has a range of AO defences, which help to maintain a balanced redox status (Rahman et al., 2006). The AOs are present intracellularly in vascular and extracellular respiratory tract lining fluid (RTLF) compartments. Glutathione peroxidases (GPx), also known as selenoproteins, are a family of AO enzymesselenoproteins expressed by endothelial cells. These enzymes reduce particularly toxic hydroperoxides. GPx is especially important in reducing the production of inflammatory prostaglandins and leucotrienås. This enzyme assumes a critical role in protecting against free-radical and oxidative damage in lungs. The activity of GPxs largely depends on selenium (Se), due to its presence at the active site of these enzymes (Brigelius-Flohe and Maiorino, 2013). Se deficiency has often been often reported in Latvia, due to low concentrations in food grown and consumed in the area. A protective effect of Se against LP has been observed and a possible mechanism of action through GPx has been proposed (Voitsekhovskaia et al., 2007). In cases of Se deficiency and with the resulting impaired function of GPx's, destructive hydrogen peroxide breaks down into even more dangerous hydroxyl radicals that damage cell membranes and cell DNA, eventually leading to OS (Rayman, 2012). Glutathione (GSH) is a frequently occuring tripeptide thiol and acts as a vital intra- and extracellular protection $\mathrm{AO}$ against oxidative/nitrosative stresses, interceding the proinflammatory processes in the lungs (Kelly, 1999; Rahman and MacNee, 2000). Reduction of GSH of respiratory tract lining fluid is severe, and studies have shown that the RTLF GSH pool plays a role in respiratory protection (Cantin et $a l .$, 1989). The rate-limiting enzyme in GSH synthesis is gamma-GCS. The human gamma-GCS heavy and light subunits are regulated by activator protein-1 and AO response elements and are modulated by oxidants, phenolic AOs, growth factors, and inflammatory and anti-inflammatory agents in lung cells (Rahman and MacNee, 2000). GPx4 catalyses lipid peroxide banding by GSH; this reaction occurs at the selenocysteine $(\mathrm{Sec})$ within the catalytic center of GPx4. The active selenol - $\mathrm{SeH}$ is oxidised by peroxides to selenenic acid - $\mathrm{SeOH}$ during the catalytic cycle of GPx4, which is then reduced with GSH to an intermediate selenodisulfide (Yoo et al., 2010). The resulting concentrations of GSH depend on GSH oxidation by several hydroperoxides, GSH conjugation to electrophiles and participation in protein folding, and export and import of GSH and its compartmental amino acids (particulary Sec). Along the scavenger pathway, Sec is employed by gamma-glutamyl transferase to bypass glutamate cysteine ligase (Ursini et al., 2016).

Changes in GSH metabolism of the alveoli and the lungs are a main feature of several inflammatory lung diseases, notably, asthma, cystic fibrosis, acute respiratory distress syndrome and idiopathic pulmonary fibrosis (Rahman and MacNee, 2000).

Superoxide dismutase (SOD) appears to be another important AO defense against ROS. SOD belongs to a family of enzymes that function to efficiently catalyse the dismutation of superoxide anions. Evidence supports the notion that lack of SOD contributes to impaired angiogenesis, vascular abnormality, increased vasoconstriction and endothelial dysfunction (Groleau et al, 2010).

The aim of the study was to evaluate oxidative stress parameters in patients with pneumonia.

\section{MATERIALS AND METHODS}

The prospective and randomised study included patients with radiologically approved CAP: 73 previously healthy 
adults, 31 male and 42 female, with mean age $68.0 \pm 15.2$, hospitalised in the Pulmonology and Allergology Department of Pauls Stradinš Clinical University Hospital (Rīga, Latvia) from 1 January 2015 to 31 December 2015. The clinical diagnosis was based on CAP symptoms (acute onset, increased body temperature, and cough with/without sputum) and auscultative findings. Radiologic approval of diagnosis was obtained from the first chest $\mathrm{x}$-ray or computer tomography scan. In addition, 61 healthy age-matched controls were recruited: 4 males and 57 females. Past history of smoking was considered as well.

To assess CAP severety, the Pneumonia Severety Index (PSI) was applied (Fine et al., 1997). PSI assigns points based on age and presence of coexisting disease, abnormal physical findings (such as respiratory rate $\geq 30$ or temperature $\geq 40$ degrees $\mathrm{C}$ ), and abnormal laboratory findings (such as $\mathrm{pH} .35$, blood urea nitrogen concentration30 $\geq \mathrm{mg}$ $\mathrm{dl}^{-1}$ or sodium concentration $<130 \mathrm{mmol} \mathrm{l}^{-1}$ ). Risk using a score of $\mathrm{I}-\mathrm{V}$ was estimated based on percentage risk of death within 30 days.

The study protocol, the agreement and participation protocols were in accordance with the Declaration of Helsinki of Humanity in Medicine and were approved by the Commission on Ethics of Rīga Stradiņš University, Latvia (RSU). There was no conflict of interest. All laboratory tests were performed in the Biochemical Laboratory of RSU (EU certified).

Blood samples were collected after overnight fast ( 10-12 hours). Fresh venous blood samples were collected into vacuum tubes (BD Vacutainer ${ }^{\mathrm{TM}}$ ) containing anticoagulant lithium heparin and centrifuged at $1600 \mu \mathrm{g}$ for 10 minutes at $4{ }^{\circ} \mathrm{C}$. The plasma and buffy coat were separated. Chemically pure reactants (analytical grade) from Merck (Darmstadt, Germany), $\mathrm{H}_{2} \mathrm{O}_{2}$ from Sigma-Aldrich (St. Luis, USA) were used; water was double distilled (distillation apparatus from Sanyo Gallenkamp PLC, Leicester, UK). Inter-laboratory quality control was conducted using two standards - Se AAS solution (Aldrich, USA, Cat No. 24, 792-8) and Seronorm TE Serum Level I (from Synlab diagnostic GmbH, Germany) for the Seronorm ${ }^{\mathrm{TM}}$ Trace Elements-Controls Programme; external quality assessment services were implemented by Labquality Oy, Finland.

Variables were presented as mean \pm standard deviation or median (interquartile range). Mann-Whitney $U$-tests were used to compare CAP and healthy control groups. SPSS for Windows version 23.0 (USA) was used for statistical analyses. Statistical significance of mean values was evaluated by means of the paired-samples T-Test. A $p$ value $<0.05$ was considered as statistically significant in all analyses. Interrelationship between parameters was evaluated by the Wilcoxon correlation coefficient.

Plasma Se was determined fluorimetrically (Alfthan, 1984).

Activity of GPx was determined in heparinised whole blood using commercial tests manufactured by Randox Labora- tories (UK, Antrium) in a RX Daytona analyser. The assay products were measured by the method of Paglia and Valentine (Paglia and Valentine, 1967).

Plasma MDA was measured by means of high-performance liquid chromatography (Esterbauer and Cheesman, 1990). The method allowed to distinguish between separate MDA and MDA together with HNE.

$\mathrm{Cu}, \mathrm{Zn}$ - SOD activity was determined according to the method of Woolliams et al. (Woolliams et al., 1983) using a RANDOX (RANSOD) kit.

GSH was determined by the method of Beutler et al. (Beutler et al., 1963).

\section{RESULTS}

The study included 73 patients with mean age $68.0 \pm 15.2$ : 31 males $(42.5 \%)$ and 42 females $(57.5 \%)$. PSI was determined in all 73 patients $(100 \%)$.

Mean values for PSI scores and OS parameters were as follows (Tables 1-3, Fig. 1):

Lower levels of GSH and plasma selenium were observed in CAP vs control groups (Tables 1,2 ). We also noted reduced activity of some antioxidant enzymes (GPX and SOD) in CAP patients vs healthy controls (Tables 1, 2). A low antioxidant enzymes activity was associated with a

Table 1

BIOMARKER LEVELS AND PSI IN THE PATIENT GROUP

\begin{tabular}{l|c|c|c|c}
\hline \multirow{2}{*}{\multicolumn{1}{c|}{ Parameter }} & \multicolumn{4}{c}{ Gender } \\
\cline { 2 - 5 } & \multicolumn{2}{|c}{ male } & \multicolumn{2}{c}{ female } \\
\cline { 2 - 5 } & mean & $\begin{array}{c}\text { standard } \\
\text { deviation }\end{array}$ & mean & $\begin{array}{c}\text { standard } \\
\text { deviation }\end{array}$ \\
\hline Age & 67.0 & 14.0 & 69.7 & 17.6 \\
Pneumonia Severity Index & 99.7 & 28.8 & 111.3 & 104.4 \\
GSH, mmol/l & 1.11 & 0.20 & 1.12 & 0.24 \\
$\mathrm{Se}, \mathrm{mg} / \mathrm{l}$ & 70.28 & 18.38 & 64.41 & 23.04 \\
$\mathrm{SOD}, \mathrm{U} / \mathrm{g} \mathrm{Hb}$ & 1580 & 343 & 1709 & 263 \\
$\mathrm{GPx}, \mathrm{U} / \mathrm{ml}$ & 6070 & 1885 & 6017 & 1783 \\
$\mathrm{MDA}, \mu \mathrm{M}$ & 1.44 & .38 & 1.50 & 45 \\
$\mathrm{HNE}, \mu \mathrm{M}$ & 2.56 & 1.19 & 2.56 & 1.15 \\
$\mathrm{MDA}+\mathrm{HNE}, \mu \mathrm{M}$ & 4.01 & 1.10 & 4.06 & 1.12 \\
& & & &
\end{tabular}

BIOMARKER LEVELS AND PSI IN THE CONTROL GROUP

\begin{tabular}{lccc}
\hline \multicolumn{1}{c}{ Parameter } & Mean & Standard Deviation \\
\hline Age & 68.3 & 15.4 \\
GSH, mmol/l & 1.20 & 0.16 \\
$\mathrm{Se}, \mathrm{mg} / \mathrm{l}$ & 74.61 & 18.41 \\
$\mathrm{SOD}, \mathrm{U} / \mathrm{g} \mathrm{Hb}$ & 1663 & 169.64 \\
$\mathrm{GPx}, \mathrm{U} / \mathrm{ml}$ & 7719 & 1741 \\
$\mathrm{MDA}, \mu \mathrm{M}$ & 1.14 & 0.55 \\
$\mathrm{HNE}, \mu \mathrm{M}$ & 2.92 & 1.26 \\
MDA+HNE, $\mu \mathrm{M}$ & 4.06 & 0.91
\end{tabular}


BIOMARKER LEVELS IN PATIENTS - SMOKERS VS. NON-SMOKERS

\begin{tabular}{|c|c|c|c|c|c|c|c|c|}
\hline \multirow{5}{*}{ Parameter } & \multicolumn{8}{|c|}{ Gender } \\
\hline & \multicolumn{4}{|c|}{ male } & \multicolumn{4}{|c|}{ female } \\
\hline & \multicolumn{4}{|c|}{ smoker } & \multicolumn{4}{|c|}{ smoker } \\
\hline & \multicolumn{2}{|c|}{ no } & \multicolumn{2}{|c|}{ yes } & \multicolumn{2}{|c|}{ no } & \multicolumn{2}{|c|}{ yes } \\
\hline & mean & stand. deviat. & mean & stand. deviat. & mean & stand. deviat. & mean & stand. deviat \\
\hline Age & 71.3 & 14.4 & 64.8 & 14.8 & 73.9 & 17.4 & 61.3 & 15.6 \\
\hline PSI & 108.3 & 28.0 & 95.2 & 33.8 & 124.4 & 149.4 & 95.0 & 43.8 \\
\hline GSH, mmol/1 & 1.15 & 0.18 & 1.12 & 0.24 & 1.09 & 0.23 & 1.16 & 0.37 \\
\hline $\mathrm{Se}, \mathrm{mg} / \mathrm{l}$ & 88.91 & & 52.15 & & 71.47 & 25.28 & 52.65 & 15.76 \\
\hline $\mathrm{SOD}, \mathrm{U} / \mathrm{g} \mathrm{Hb}$ & 1803 & 260 & 1546 & 335 & 1734 & 274 & 1747 & 191 \\
\hline GPx, U/ml & 6682 & 1709 & 5821 & 2105 & 6264 & 1866 & 3966 & 454 \\
\hline MDA, $\mu \mathrm{M}$ & 1.74 & 0.23 & 1.32 & 0.40 & 1.57 & 0.47 & 1.43 & 0.42 \\
\hline $\mathrm{HNE}, \mu \mathrm{M}$ & 3.00 & 1.50 & 2.61 & 1.40 & 2.12 & 0.91 & 4.14 & 0.32 \\
\hline $\mathrm{MDA}+\mathrm{HNE}, \mu \mathrm{M}$ & 4.74 & 1.28 & 3.93 & 1.24 & 3.69 & 0.98 & 5.57 & 37 \\
\hline
\end{tabular}

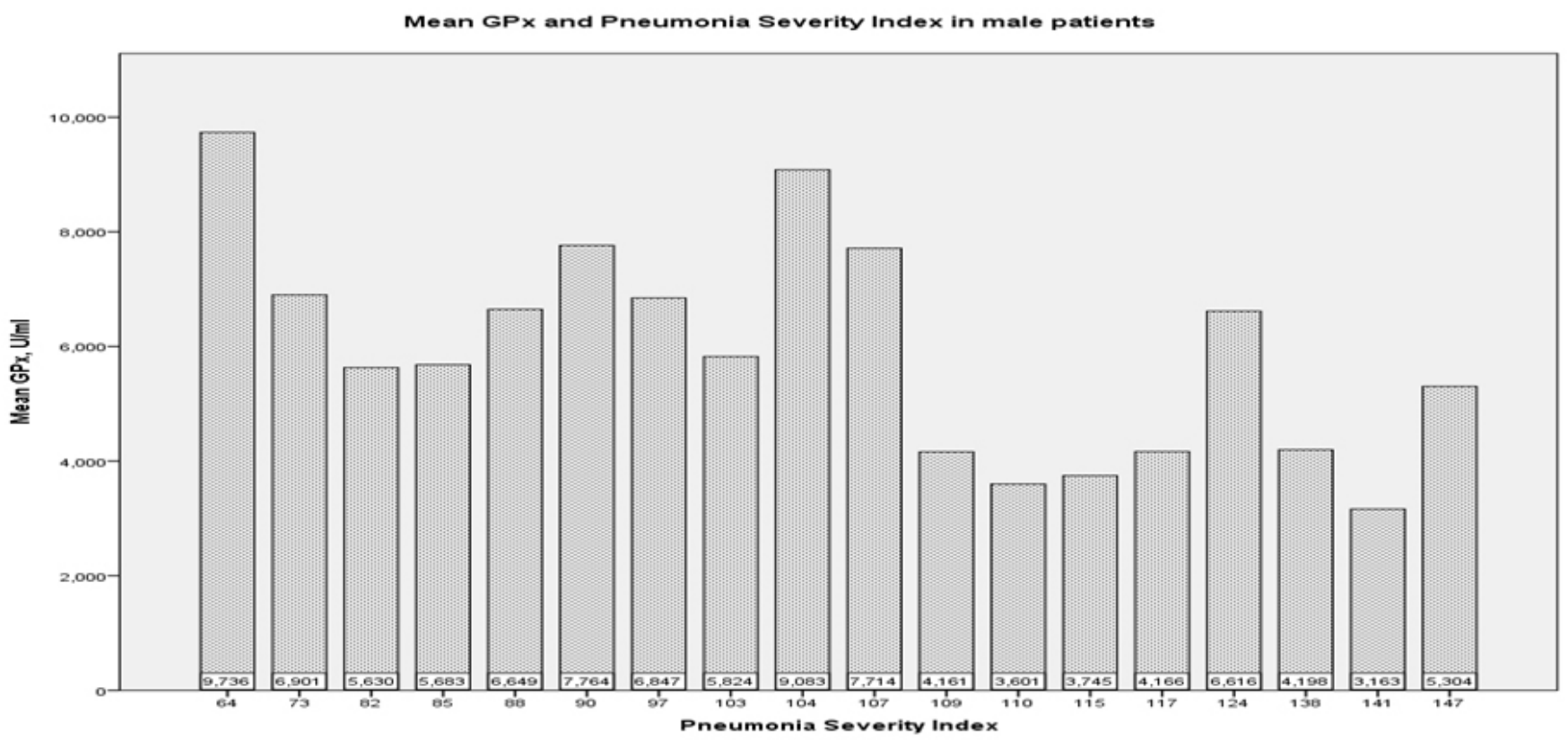

Fig. 1. Mean GPx and Pneumonia Severity Index in male patients.

more severe CAP pattern (Table 3). There was negative correlation between GPx and PSI as well as between SOD and PSI in male patients (Fig. 1). We assume that antioxidant enzymes were significantly reduced in this patient group due to the high proportion of smokers in the group.

We did not find significant elevation of HNE and MDA (Tables 1, 2). Slightly higher levels of MDA/HNE occurred in all patients, and were obviously elevated in female smokers (Table 3). However, in a few patients the MDA/HNE level was surprisingly low, resulting in mean values that were at normal levels, i.e. comparable to healthy controls.

\section{DISCUSSION}

We recommend that GPx, SOD, and GSH levels are considered in evaluation of CAP severity. OS parameters provide additional value in CAP severity evaluation together with well-known inflammatory markers (C-reactive protein, leucocytes, etc). The combination of several biomarkers reflecting different pathophysiological pathways might have potential in improving management of CAP in the future.

The most controversial seem to be the MDA/HNE results. We expected high MDA/HNE levels in cases of OS in CAP. Numerous patients had extremely low MDA/HNE levels, demonstrating a very severe CAP pattern and need for intravenous fluid. Plasma dilution might have affected MDA/HNE results. GPx, SOD, GSH were tested using erythrocyte substrate, and thus no effect of intravenous fluid was noted.

Lower levels of GSH in CAP patients have been observed also in other studies (Kelly, 1999; Rahman and MacNee, 2000; Castillo R. et al., 2013) and suggest that deficit of 
GSH might predispose to pulmonary inflammation. The protective role of GSH in regard to the lower respiratory tract has been suggested; hence, use of GSH inhalations might be beneficial for cystic fibrosis treatment (Prousky, 2008; Day, 2005). In our study, the relatively small sample size of the patientcohort was a limitation. We nevertheless believe that the data obtained are meaningful and should prompt further large-scale investigations. There is evidence of systemic OS and systemic inflammation in CAP. We believe that lower GSH and antioxidant enzyme activity are features of CAP manifestation and that measurement of these biomarkers (GPx, SOD, GSH) in blood can be a valid index in the management of CAP to assess the status of OS, inflammation, and to predict CAP severity and/or complications. We would like to emphasise once again that in clinical practice, there is a risk of underestimating the severity of the patient with CAP using standard criteria, making it necessary to continue investigations regarding the use of biological markers of adverse clinical outcomes.

Considering the study results we conclude, that:

1. Se deficiency in the CAP patients, inhabitants of Latvia, was shown: average Se plasma level in CAP patients was $66.01 \mathrm{mcg} / \mathrm{l}$, in healthy controls: $74.61 \mathrm{mcg} / \mathrm{l}$. The mean level in Europe is $80-120 \mathrm{mcg} / \mathrm{l}$ (Rayman, 2012). The degree of Se deficiency in CAP patients seems to be comparable to that of the entire population.

2. Decreased activity of both GPx and SOD was associated with a significant decrease of GSH concentration, indicating rapid consumption of GSH via GPx reaction. Decreased SOD and GPx activity was associated with a more severe CAP pattern.

3. GSH, GPx and SOD can be used as markers for inflammation-related OS in CAP patients and measurement of these biomarkers can be a valid index in CAP severity assessment and management.

4. Regarding MDA/HNE level: we believe that special attention should be paid to the procedure of blood sample collection (to avoid collection after intravenous fluid administration). Determination of MDA/HNE in erythrocytes, not plasma, would be prefered.

The views expressed in this article are those of the authors and do not reflect the official policy or position of the Latvian Ministry of Health or any of the institutions with which the authors are affiliated. All authors read and approved the final manuscript.

\section{REFERENCES}

Alfthan, G. (1984). A micromethod for the determination of selenium in tissues and biological fluids by single-test-tube fluorimetry. Anal. Chim. Acta, 165, 187-194.

Barnes, P. (1990). Reactive oxygen species and airway inflammation. Free Radic. Biol. Med., 9, 235-243.

Beutler, E., Duron, O., Kelley, B. M. (1963). Improved method for the determination of blood glutathione. J. Lab. Clin. Med., 61, 882-888.
Brigelius-Flohe, R., Maiorino, M. (2013). Glutathione peroxidases. Biochim. Biophys. Acta, 1830 (5), 3289-3303.

Cantin, A., Hubbard, R., Crystal, S. (1989). Glutathione deficiency in the epithelial lining fluid of the lower respiratory tract in idiopathic pulmonary fibrosis. Amer. Rev. Respir. Dis., 139 (2), 370-372.

Castillo, R. L., Carrasco, R. A., Álvarez, P. I., Ruiz, M., Luchsinger, V., Zunino, E., Martínez, M. A., Avendańo, L. F. (2013). Relationship between severity of adult community acquired pneumonia and impairment of the antioxidant defense system. Biol. Res., 46 (2), 207-213.

Dalle-Donne, I., Rossi, R., Colombo, R., Giustarini, D., Milzani, A. (2006). Biomarkers of oxidative damage in human disease. Clin. Chem., 52 (4), 601-623.

Day, B. J. (2005). Glutathione: A radical treatment for cystic fibrosis lung disease. Chest, 127 (1), 12-14.

Esterbauer, H., Cheesman K. (1990). Determination of aldehydic lipid peroxidation products: malonaldehyde and 4-hydroxynonenal. Methods Enzymol., 186, 407-421.

File, T. (2003). Community-acquired pneumonia. Lancet, 362, 1991-2001.

Fine, M., Auble, T., Yealy, D., Hanusa, B., Weissfeld, L., Singer, D., Coley, C., Marrie, T., Kapoor, W. (1997). A prediction rule to identify low-risk patients with community-acquired pneumonia. New Engl. J. Med., 336 (4), 243-250.

Frei, C., Attridge, R., Mortensen, E., Restrepo, M., Yu, Y., Oramasionwu, C., Ruiz, J., Burgess, D. (2010). Guideline-concordant antibiotic use and survival among patients with community-acquired pneumonia admitted to the intensive care unit. Clin. Ther., 32 (2), 293-299.

Groleau, J., Dussault, S., Haddad, P., Turgeon, J., Menard, C., Chan, J., Rivard, A. (2010). Essential role of copper-zinc superoxide dismutase for ischemia-induced neovascularization via modulation of bone marrowderived endothelial progenitor cells. Arterioscler. Thromb Vasc. Biol., 30, 2173-2181.

Kelly, F. (1999). Gluthathione: in defence of the lung. Food Chem Toxicol, 37, 963-966.

Nickler, M., Schaffner, D., Christ-Crain, M., Ottiger, M., Thomann, R., Hoess, C., Henzen, C., Mueller, B., Schuetz, P. (2016). Prospective evaluation of biomarkers for prediction of quality of life in community-acquired pneumonia. Clin. Chem. Lab. Med., 32 (4), 334-341.

Nathan, C., Cunningham-Bussel, A. (2013). Beyond oxidative stress: An immunologist's guide to reactive oxygen species. Nature Rev. Immunol., 13 (5), 349-361.

Paglia, D., Valentine, W. (1967). Studies on the quantitative and qualitative characterization of erythrocyte glutathione peroxidase. J. Lab. Clin. Med., 70, 158-169.

Poli, G., Schaur, R., Siems, W., Leonarduzzi, G. (2008). 4-hydroxynonenal: A membrane lipid oxidation product of medicinal interest. Med. Res. Rev., 28 (4), 569-631.

Prousky, J. (2008). The treatment of pulmonary diseases and respiratoryrelated conditions with inhaled (nebulized or aerosolized) glutathione. Evid. Based Complement. Alternat. Med., 5 (1), 27-35.

Rahman, I., MacNee, W. (2000). Oxidative stress and regulation of glutathione in lung inflammation. Eur. Respir. J., 16 (3), 534-554.

Rahman, I, van Schadewijk, A., Crowther, A., Hiemstra, P., Stolk, J., MacNee, W., De Boer, W (2002). 4-hydroxy-2-nonenal, a specific lipid peroxidation product, is elevated in lungs of patients with chronic obstructive pulmonary disease. Amer. J. Respir. Crit. Care Med., 166, 490-495.

Rahman, I., Biswas, S., Kode, A. (2006). Oxidant and antioxidant balance in the airways and airway diseases. Eur. J. Pharmacol., 533 (1-3), 222-239.

Rayman, M. (2012). Selenium and human health. Lancet, 379 (9822), 1256-1268.

Schaur, R., Siems, W., Bresgen, N., Eckl, P. (2015). 4-Hydroxy-nonenal - a bioactive lipid peroxidation product. Biomolecules, 5, 2247-2337. 
Taivans, I., Jurka, N., Skesters, A., Strazda, G. (2001). Cell spectrum and oxidant/anti-oxidant status of induced sputum in smokers with airway obstruction versus smokers without obstruction and nonsmokers. Eur. Respir. J., 18 (33), 92.

Ursini, F., Maiorino, M., Forman, H. (2016). Redox homeostasis: The Golden Mean of healthy living. Redox. Biol., 8, 205-215.

Voitsekhovskaia, J., Skesters, A., Orlikov, G., Silova, A., Rusakova, N., Larmane, L., Karpov, J., Ivanov, A., Maulins, E. (2007). Assessment of some oxidative stress parameters in bronchial asthma patients beyond add-on selenium supplementation. Biomed. Khim., 53 (5), 577-584.

Watson, J. (2014). Type 2 diabetes as a redox disease. The Lancet, 383 (9919), 841-843.

Received 17 October 2016

Accepted in the final form 18 October 2016
Welte, T., Torres, A., Nathwani, D. (2012). Clinical and economic burden of community-acquired pneumonia among adults in Europe. Thorax, 67, $71-79$.

Woolliams, J., Wiener, G., Anderson, P., McMurray, C. (1983). Variation in the activities of glutathione-peroxidase and superoxide-dismutase and in the concentration of copper in the blood in various breed crosses of sheep. Res. Vet. Sci., 34, 253-256.

Wunderink, R., Waterer, G. (2014). Clinical practice. Community-acquired pneumonia. New Engl. J. Med., 370 (6), 543-551.

Yoo, M., Gu, X., Xu, X., Kim, J., Carlson, B., Patterson, A., Cai, H., Gladyshev, V., Hatfield, D. (2010). Delineating the role of glutathione peroxidase 4 in protecting cells against lipid hydroperoxide damage and in Alzheimer's disease. Antioxid. Redox. Signal., 12, 819-827.

\section{BIOMARK়IERI SABIEDRĪBĀ IEGŪTAS PNEIMONIJAS GAITAS NOVĒRTĒŠANAI}

Rakstā apkopota informācija par oksidatīvā stresa (OS) rādītājiem pacientiem ar pneimoniju (P). OS pazīmju noteikšana pacientiem ar P ir svarīga ne tikai diagnostiskā procesa vadīšanai, bet arī terapijas efektivitātes novērtěšanā. Mēs atlasījām 73 pacientus ar sabiedrībā iegūto pneimoniju (SIP), iepriekš veselus pieaugušos, vīriešus un sievietes ar vidējo vecumu 68 gadi, kas bija stacionēti nodalāa, un 61 kontroles pacientu atbilstošā vecuma. Kvantitatīvai lipīdu peroksidācijas novērtěšanai SIP pacientu vidū noteicām aldehīdu grupas peroksidācijas vielas - malondialdehīdu (MDA) un 4-hidroksinon-2-enal (HNE). Pētījuma laikā tika noteikta glutationa (GSH) un citu antioksidantu enzīmu aktivitāte, kā arī plazmas selēna daudzums. SIP pacientu vidū novērojām samazinātu GSH un selēna daudzumu, kā arī antioksidatīvo enzīmu, īpaši glutationa peroksidāzes un superoksīddismutāzes aktivitāti. Plazmas MDA un HNE rezultāti bija pretrunīgi, salīdzinot ar kontroles grupu. Mazināts antioksidatīvo enzīmu skaits tika saistīts ar smagāku SIP klīnisko ainu, salīdzinot ar kontroli. Aprakstîtie novērojumi bija izteiktāki pacientu smēkēetāju vidū. GSH un antioksidatīvo enzīmu aktivitāte var kalpot kā biomarkieri pie iekaisuma mediētā OS pacientiem ar SIP, un šos parametrus iespējams pielietot slimības vadīšanā. 